\title{
Acometimento ocular em pacientes com mansonelose
}

\author{
Ocular manifestations in mansonelliasis
}

\author{
Jacob Moysés Cohen ${ }^{1}$ \\ Jefferson Augusto Santana Ribeiro ${ }^{2}$ \\ Marilaine Martins ${ }^{3}$
}

\begin{tabular}{|l|}
\hline \multicolumn{1}{c|}{ RESUMO } \\
\hline Objetivos: Avaliar as alterações oculares observadas em indivíduos com \\
mansonelose residentes na área rural do município de Coari, AM, na região \\
do médio Amazonas. Métodos: Foi conduzido um estudo de corte trans- \\
versal envolvendo 543 moradores residentes na área rural do município de \\
Coari, na margem direita do rio Solimões. Todos os indivíduos foram \\
submetidos a exame de gota espessa para pesquisa de microfilária e os \\
indivíduos positivos foram submetidos a exame oftalmológico. Lesões \\
oculares suspeitas foram biopsiadas e enviadas para exame histopatoló- \\
gico. Resultados: Mansonella ozzardi foi encontrada no sangue perifé- \\
ricoem 103(18,9\%)indivíduos. Noventae cincopacientes commansonelose \\
foram examinados, observando ceratite puntata em 12 (11,7\%) destes, \\
ceratite numular em um indivíduo (1\%) e esclerosante em outro (1\%). \\
Biópsia de pele foi negativa em todos os indivíduos. Biópsia de conjuntiva \\
e limbo foi realizada em cinco pacientes com mansonelose e biópsia de \\
córnea em outros três pacientes. Duas biópsias de conjuntiva elimbo e uma \\
biópsia de córnea foram enviadas para exame histopatológico, não sendo \\
observadas microfilárias ou alterações sugestivas da presença destas nas \\
peças estudadas. O restante das biópsias foi enviado para pesquisa de \\
DNA do parasita por PCR, não se encontrando microfilária. Conclusões: \\
Associação entre infecção por Mansonella ozzardi e lesões corneanas \\
sem etiologia aparente foi verificada neste estudo, mas a ausência de \\
achados específicos no exame histopatológico e a não identificação de \\
microfilárias porPCRem lesões suspeitas põemem dúvidaa acometimento \\
corneano na mansonelose. Estudos mais amplos de populações com alta \\
prevalência de $M$. ozzardi e a realização de outros testes para identifica- \\
ção de microfilárias em tecido ocular são necessários para investigar a \\
patogenicidade da microfilária ao tecido ocular.
\end{tabular}

Descritores: Mansonelíase/epidemiologia; Infecções oculares parasitárias; Ceratite/etiologia; Microfilária

\section{INTRODUÇÃO}

A Mansonella ozzardi (Manson, 1897) Faust, 1929, é uma filária de distribuição geográfica restrita ao continente americano $^{(1-2)}$, sendo observada em quase todos os países da América Latina ${ }^{(1)}$. No Brasil, a M. ozzardi é encontrada em áreas da floresta amazônica, no Amazonas em localidades às margens do rio Solimões e seus afluentes principais, e, fora do Amazonas, em Roraima e no Mato Grosso ${ }^{(1)}$.

A M. ozzardi é um nematódeo cujas microfilárias são encontradas no sangue periférico, podendo ser identificadas por suas características morfológicas: ausência de bainha, pequeno tamanho, núcleos somáticos compactamente distribuídos e não alcançando a extremidade posterior, relativamente afilada $^{(1)}$, ou por meio da biologia molecular (genoma) $)^{(3)}$. 
A transmissão da $M$. ozzardi é feita por dois grupos de insetos: ceratopogonídeos e simulídeos ${ }^{(4)}$.

A mansonelose é a infecção causada pela $M$. ozzardi. Os indivíduos infectados em geral são assintomáticos, podendo, porém, apresentar lesões cutâneas e oftalmológicas e um quadro geral inespecífico, embora as características clínicas da mansonelose ainda não sejam bem descritas. As lesões oculares se devem possivelmente à presença do verme nas estruturas oculares, sendo referidos prurido ocular, conjuntivite e lesões corneanas $^{(5)}$.

O município de Coari, AM, localizado no médio Amazonas, é uma região com poucos registros oftalmológicos, estando desconhecidas ainda suas doenças oculares prevalentes e possíveis necessidades. Investigações sobre mansonelose em Coari revelaram uma taxa de infecção de cerca de $15 \%$ da população ${ }^{(6)}$.

Este estudo foi realizado com o objetivo de avaliar as alterações oculares verificadas em indivíduos com mansonelose residentes na área rural do município de Coari, AM, na região do médio Amazonas.

\section{MÉTODOS}

Foi conduzido um estudo de corte transversal no mês de agosto de 2006, com avaliação de moradores residentes na área rural do município de Coari, na margem direita do rio Solimões.

Uma equipe multidisciplinar composta de dois infectologistas, dois dermatologistas, dois oftalmologistas, três biólogos e pessoal de apoio foram estabelecidos em um barco. Subindo o rio Solimões a partir de Coari, comunidades rurais ribeirinhas previamente determinadas foram visitadas pela equipe após aviso por rádio. As comunidades estudadas foram: São Francisco do Laranjal (S $03^{\circ} 53.446$ '/W $063^{\circ} 25.946$ '), Santa Luzia da Fazendinha (S 03 $\left.52.112^{\prime} / \mathrm{W} 063^{\circ} 28.900^{\prime}\right)$, São Sebastião de Porto Queiroz (S 0352.628'/W 06339.093'), Vila Lira (S $\left.03^{\circ} 56.741^{\prime} / \mathrm{W} 063^{\circ} 10.952^{\prime}\right)$, Cajuiri Atravessado (S 03⒌751'/ W 0632 $1.322^{\prime}$ ), Santa Isabel do Barro Alto (S 0352.467'/ W $063^{\circ} 47.150^{\prime}$ ') e São Pedro da Vista Alegre.

Os indivíduos foram encaminhados para consulta médica após visita domiciliar, realizada em todas as moradias de cada comunidade. Infectologistas e dermatologistas realizaram o atendimento inicial dos indivíduos em terra, após assinatura de termo de consentimento livre e esclarecido. Pesquisa de microfilárias em gota espessa foi realizada nos moradores consultados. Aqueles que apresentavam exame positivo para microfilária eram também submetidos à biópsia cutânea e encaminhados para atendimento oftalmológico. Alguns indivíduos com resultado negativo para microfilária também foram referidos para exame oftalmológico em alguns casos selecionados na triagem médica por apresentarem queixas visuais, dentre as quais olho vermelho, irritação ocular e prurido ocular.

A avaliação oftalmológica foi realizada no intuito de pesquisar lesões oculares relacionadas à mansonelose e constitui do preenchimento de um protocolo constando de exame de refração computadorizado sem cicloplegia, inspeção das estruturas oculares e motilidade ocular, biomicroscopia, gonioscopia com lente de Zeiss e oftalmoscopia binocular indireta com lente de $28 \mathrm{D}$. Pacientes com doenças oculares foram tratados, quando possível, ou referidos para tratamento em centro especializado. Pacientes com lesões suspeitas, definidas como nódulos conjuntivais, ceratites puntata, eslerosante e numular sugestivas de etiologia por M. ozzardi, foram submetidos à biópsia de conjuntiva e limbo ou biópsia de córnea para pesquisa de microfilária por meio de PCR (polymerase chain reaction) ou exame histopatológico com coloração hematoxilina-eosina.

\section{RESULTADOS}

Quinhentos e quarenta e três moradores das comunidades estudadas foram submetidos a exame de gota espessa para pesquisa de microfilária, sendo $103(18,9 \%)$ positivos. Cento e dez indivíduos foram submetidos a exame oftalmológico, 59 $(53,6 \%)$ do gênero masculino e $51(46,4 \%)$ do gênero feminino. Destes indivíduos $95(86,4 \%)$ foram positivos e $15(13,6 \%)$ negativos para $M$. ozzardi.

Com relação à comunidade de origem, os pacientes se distribuíram da forma descrita na tabela 1 .

Considerando-se a ocupação dos indivíduos atendidos, observou-se que a maioria trabalhava na agricultura em tempo integral (62 indivíduos).

Com relação às queixas dos indivíduos com mansonelose, verificou-se que diminuição da acuidade visual (AV) e ausência de queixas foram mais freqüentes, correspondendo a 35 e 27 indivíduos respectivamente. (Tabela 2)

Ao perguntar aos indivíduos com mansonelose sobre doenças preexistentes, verificou-se que doenças oculares e sistêmicas conhecidas foram pouco freqüentes. (Tabela 3)

No exame de pálpebras e cílios dos indivíduos com mansonelose, observaram-se alterações devidas ao tracoma em 7 casos. (Tabela 4) Destes casos de tracoma, um era inflamação tracomatosa intensa (TI), dois com inflamação tracomatosa folicular (TF) e quatro com cicatrização tracomatosa (TS).

A motilidade ocular dos pacientes estudados esteve preservada em todos os casos, não se verificando heterotropias.

Ao exame da câmara anterior, não se evidenciaram celularidade, hipópio, hifema, precipitados ceráticos, sinéquias anteriores ou posteriores ou atrofia de íris em nenhum dos 95 pacientes com mansonelose, sendo, porém, observados nódulos na íris de dois destes pacientes (Figuras 1 e 2).

Dez indivíduos com microfilária apresentaram catarata (10,5\% de 95 pacientes).

Gonioscopia foi realizada em 67 dos 95 pacientes com mansonelose, não se evidenciando lesões no ângulo camerular. A maioria destes pacientes (53 indivíduos, 79,1\%) apresentava ângulo aberto e com pouca pigmentação (60 indivíduos, 89,6\%).

Alterações conjuntivais foram observadas em 33 pacientes, correspondentes a $34,7 \%$ dos 95 indivíduos positivos para microfilária (Tabela 5). 
No exame do segmento posterior, $13(13,7 \%)$ dos 95 pacientes com mansonelose apresentaram alterações. As mais frequientes foram cicatrizes coriorretinianas em três pacientes e escavação glaucomatosa do disco, em outros dois indivíduos.

\begin{tabular}{|lcc|}
\hline \multicolumn{3}{|c|}{$\begin{array}{c}\text { Tabela 1. Distribuição dos pacientes atendidos nas comunidades } \\
\text { do município de Coari-AM, em agosto de }\end{array}$} \\
$\begin{array}{l}\text { Co06 } \\
\text { Comunidade }\end{array}$ & No & Freqüência (\%) \\
Cajuiri Atravessado & 4 & $3,6 \%$ \\
Coari (área urbana) & 7 & $6,4 \%$ \\
Santa Isabel do Barro Alto & 36 & $32,7 \%$ \\
Santa Luzia da Fazendinha & 7 & $6,4 \%$ \\
São Francisco do Laranjal & 7 & $6,4 \%$ \\
São Pedro da Vista Alegre & 3 & $2,7 \%$ \\
São Sebastião de Porto Queiroz & 11 & $10,0 \%$ \\
Vila Lira & 35 & $31,8 \%$ \\
Total & 110 & $100,0 \%$ \\
\hline
\end{tabular}

Tabela 2. Distribuição dos pacientes com mansonelose atendidos nas comunidades do município de Coari-AM, em agosto de 2006, segundo a queixa principal $(n=95)$

\begin{tabular}{lrr|} 
Queixa & No & Freqüência (\%) \\
Sem queixas & 27 & $28,4 \%$ \\
Irritação ocular & 12 & $12,6 \%$ \\
Diminuição da acuidade visual & 35 & $36,8 \%$ \\
Dor ocular & 9 & $9,5 \%$ \\
Fotofobia & 1 & $1,1 \%$ \\
Olho vermelho & 2 & $2,1 \%$ \\
Outras & 9 & $9,5 \%$ \\
Total & 95 & $100,0 \%$ \\
\hline
\end{tabular}

Tabela 3. Distribuição dos pacientes com mansonelose atendidos nas comunidades do município de Coari-AM, em agosto de 2006, com doenças preexistentes $(n=17)$

\begin{tabular}{lcc|} 
Condição associada & No & Freqüência (\%) \\
Pterígio & 1 & $5,9 \%$ \\
Catarata & 1 & $5,9 \%$ \\
Hipertensão arterial & 8 & $47,1 \%$ \\
Diabetes mellitus & 3 & $17,6 \%$ \\
Cirurgia ocular & 1 & $5,9 \%$ \\
Outras & 3 & $17,6 \%$ \\
Total & 17 & $100,0 \%$ \\
\hline
\end{tabular}

\begin{tabular}{|c|c|c|}
\hline \multicolumn{3}{|c|}{$\begin{array}{c}\text { Tabela 4. Distribuição dos pacientes com mansonelose atendidos } \\
\text { nas comunidades do município de Coari-AM, agosto de } 2006 \text {, } \\
\text { segundo alterações palpebrais e dos cílios }\end{array}$} \\
\hline Característica da lesão & № & Freqüência (\%) \\
\hline Triquíase & 1 & $1,1 \%$ \\
\hline Ptose & 1 & $1,1 \%$ \\
\hline Blefarite & 6 & $6,3 \%$ \\
\hline Tracoma & 7 & $7,3 \%$ \\
\hline Sem alterações & 80 & $84,2 \%$ \\
\hline Total & 95 & $100,0 \%$ \\
\hline
\end{tabular}

Com relação às alterações corneanas, a ceratite foi encontrada em 21 dos 110 pacientes; sendo 14 deles portadores de mansonelose. A frequiência de ceratite em pacientes com mansonelose foi $14,7 \%$.

As ceratites, à semelhança da classificação utilizada na onco$\operatorname{cercose}^{(7)}$, foram classificadas em puntata, esclerosante e numular (Tabela 6). A ceratite puntata foi a forma mais freqüente, ocorrendo em 12 pacientes com mansonelose (12,6\%). Nos pacientes negativos para microfilária, os sete casos verificados foram de ceratite puntata. As lesões corneanas da ceratite puntata nos pacientes com mansonelose consistiram de pequenas lesões circulares, de 1,0 a 3,0 mm de diâmetro, localizadas no estroma anterior, em área translúcida da córnea, sem vascularização e sem afetar a visão. A localização principal destas lesões foi justalimbar em nove casos e paracentral nos outros três casos. O número de puntata variou de uma a seis lesões em um único olho, havendo dois casos de acometimento bilateral com

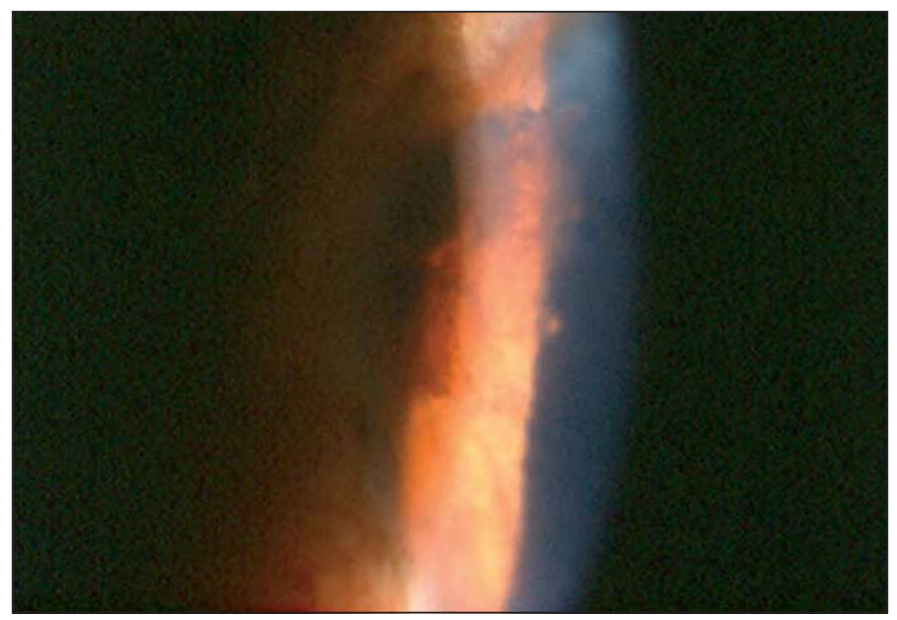

Figura 1 - Nódulo de Köeppe - sinal inflamatório do trato uveal

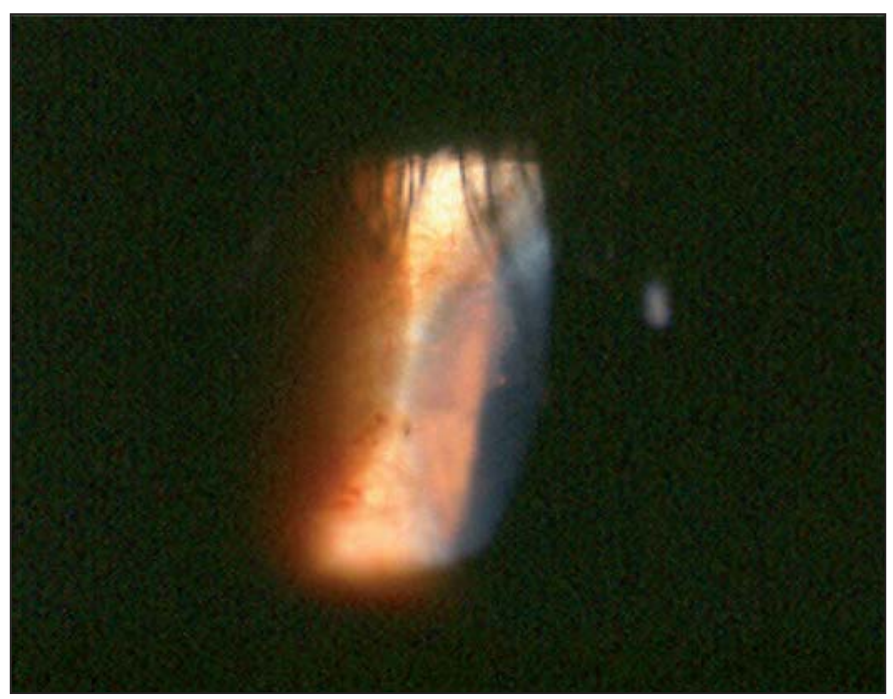

Figura 2 - Processo inflamatório do limbo (junção córneo-escleral) 


\begin{tabular}{|c|c|c|}
\hline Característica da lesão & № & Freqüência (\%) \\
\hline Hiperemia & 4 & $4,2 \%$ \\
\hline Edema & 0 & $0,0 \%$ \\
\hline Nódulos & 0 & $0,0 \%$ \\
\hline Pterígio & 27 & $28,4 \%$ \\
\hline Pinguécula & 2 & $2,1 \%$ \\
\hline Sem alterações & 62 & $65,3 \%$ \\
\hline Total & 95 & $100,0 \%$ \\
\hline
\end{tabular}

\begin{tabular}{|lcc|}
$\begin{array}{l}\text { Tabela 6. Distribuição dos pacientes com mansonelose atendidos } \\
\text { nas comunidades do município de Coari-AM, em agosto de 2006, } \\
\text { segundo as características da ceratite (n=95) }\end{array}$ \\
Ceratite & No & Freqüência (\%) \\
Ausente & 81 & $85,3 \%$ \\
Esclerosante & 1 & $1,1 \%$ \\
Numular & 1 & $1,1 \%$ \\
Puntata & 12 & $12,6 \%$ \\
Total & 95 & $100,0 \%$ \\
\hline
\end{tabular}

uma lesão puntata em cada olho. As ceratites esclerosante e numular tinham localização justalimbar, medindo entre 4,0 a 6,0 $\mathrm{mm}$ de diâmetro. O paciente com ceratite numular também apresentava cicatrização tracomatosa (TS), um outro com ceratite puntata apresentava etiologia adenoviral presumida, com quatro lesões corneanas no olho direito, outro com ceratite puntata apresentava inflamação tracomatosa intensa (TI) e outro com puntatas apresentava cicatrização tracomatosa (TS).

As lesões puntiformes nos pacientes negativos para microfilária localizavam-se anteriormente no estroma, sendo justalimbar em três casos, paracentral em outros três e central em um caso. O número de lesões puntiformes nos pacientes sem mansonelose variou de uma a quatro lesões em um único olho, havendo um caso de bilateralidade.

Biópsia de conjuntiva e limbo foi realizada em cinco pacientes com mansonelose e biópsia de córnea em outros três pacientes. Duas biópsias de conjuntiva e limbo e uma biópsia de córnea foram enviadas para exame histopatológico e coradas com hematoxilina-eosina, não sendo encontradas microfilárias ou alterações sugestivas da presença destas nas peças estudadas. O restante das biópsias foi enviado para pesquisa de DNA do parasita por PCR, não sendo conclusivos da presença de microfilárias os resultados deste exame.

\section{DISCUSSÃO}

A mansonelose é uma doença cujas características clínicas ainda não se encontram bem estabelecidas, havendo alguns autores que consideram a $M$. ozzardi não patogênica ${ }^{(2)}$. Porém, alterações dermatológicas, oculares e sintomas gerais têm sido associados à mansonelose $\mathrm{e}^{(1-2,5)}$.
Branco et al..$^{(5)}$, estudando moradores de Pauini, AM, descreveram lesões corneanas circulares, de 0,5 a 1,0 mm, com área translúcida de córnea entre a lesão e o limbo, sem neovascularização e sem afetar a visão em 20 indivíduos, sendo que, de quatro indivíduos submetidos a venóclise para pesquisa de microfilária, dois indivíduos foram positivos para Mansonella sp., não sendo encontrado oncocercose. Os autores sugeriram que as lesões corneanas sem causa conhecida e a presença de Mansonella sp. podiam refletir uma possível relação causal ${ }^{(5)}$.

Um estudo envolvendo 496 indivíduos, dentre os quais 395 índios, em São Gabriel da Cachoeira, alto rio Negro, (AM), demonstrou lesões corneanas caracterizadas por infiltrados numulares, brancos, não confluentes, menores de 2,0 $\mathrm{mm}$ de diâmetro, envolvendo o estroma anterior e médio com pequenos focos inflamatórios ${ }^{(2)}$. Os infiltrados corneanos variaram de 2 a 8 lesões por olho, geralmente localizadas na periferia, circundadas por área transparente de córnea, sem neovascularização ou reação de câmara anterior e sem afetar a acuidade visual. Dos 140 indivíduos positivos para M. ozzardi, 76 apresentaram ceratite, enquanto nenhum dos indivíduos que apresentaram resultado negativo para microfilária tinham ceratite ${ }^{(2)}$. A frequiência de ceratite foi maior em indivíduos com mais de 30 $\operatorname{anos}^{(8)}$. Não foram encontradas entre os 496 indivíduos examinados lesões oncocercóticas oculares ou dérmicas, nem filarias de Onchocerca volvulus nas biópsias de pele ${ }^{(8)}$. Os achados deste estudo fortalecem a hipótese de que a $M$. ozzardi seja patogênica para o tecido corneano ${ }^{(8)}$.

Neste estudo, lesões sugestivas de etiologia por M. ozzardi consitiram de ceratites puntata, eslerosante e numular. Dos indivíduos infectados por mansonela, 14 apresentaram ceratite, incluindo-se aí um caso de ceratite esclerosante e outro de ceratite numular. As lesões corneanas da ceratite puntata nos pacientes com mansonelose eram circulares, medindo de 1,0 a 3,0 mm de diâmetro, localizadas no estroma anterior, em área translúcida da córnea, sem vascularização e sem afetar a visão. As lesões se localizavam geralmente na periferia corneana e não estavam associadas a alteração do epitélio, afinamento corneano ou reação da câmara anterior. O número de puntata variou de uma a seis lesões em um único olho. As ceratites esclerosantes e numulares tinham localização justalimbar, medindo entre 4,0 a 6,0 mm de diâmetro. Os pacientes com ceratite presumida por mansonela não apresentavam associações com outras doenças oculares, exceto por três pacientes com catarata e um paciente, com ceratite numular, que apresentava tracoma.

Entre os indivíduos negativos para microfilária, observouse uma alta freqüência de lesões corneanas puntata, correspondendo a 46,6\% dos indivíduos, 7 dos 15 examinados. Em um destes casos o diagnóstico foi de ceratite adenoviral presumida, em outros dois havia associação com tracoma. A alta freqüência de lesões corneanas observada nos indivíduos negativos para microfilária pode ser devido ao fato de estes indivíduos terem sido encaminhados para exame oftalmológico após triagem médica e não aleatoriamente selecionados, não constituindo uma amostra representativa dos indivíduos 
negativos para microfilária, mas sendo incluídos neste artigo por demonstrarem a presença de lesões corneanas sem causa aparente, semelhantes às dos indivíduos positivos para microfilária.

Nesta pesquisa, a ausência de identificação de alterações sugestivas de presença de microfilária ao exame histopatológico, bem como a não identificação de microfilária pelo PCR nos espécimes corneanos estudados, leva-nos a questionar sobre a patogenicidade da microfilária no tecido ocular.

\section{CONCLUSÕES}

Associação entre infecção por Mansonella ozzardi e lesões corneanas sem etiologia aparente foi verificada neste estudo, mas a ausência de achados específicos no exame histopatológico e a não identificação de microfilárias por PCR em lesões suspeitas põem em dúvida o acometimento ocular na mansonelose. Estudos mais amplos de populações com alta prevalência para mansonela e com realização mais extensa de testes para identificação de microfilárias em tecido ocular, como exame histopatológico e PCR, são necessários para investigar a patogenicidade da microfilária ao tecido corneano.

\section{ABSTRACT}

Purpose: To evaluate eye manifestations in mansonelliasis patients from Coari, AM, rural area on the middle Amazonas River. Methods: Cross-sectional study consisted of evaluation of 543 subjects from Coari rural area on Solimões River right margin. All subjects were submitted to blood test for microfilaria and the subjects who had a positive test also were submitted to skin biopsies and ophthalmologic examination. Histopathology and PCR research for microfilaria were done on eye biopsies of suspect lesions. Results: Mansonella ozzardi was found in peripheral blood of 103 (18.9\%) subjects. Ninety-five mansonelliasis patients were examined. Punctate keratitis was observed in 12 of them, nummular keratitis in one subject and sclerosing keratitis in another one. Skin biopsies were negative in all subjects. Conjunctival and limbal biopsies were done in five mansonelliasis patients and corneal biopsy in another three patients. Conjunctival and limbal biopsies of two patients and corneal biopsy of one patient showed no microfilaria or alterations due to its presence on histopathology. PCR showed no evidence of microfilaria in the other biopsies. Conclusion: Association between Mansonella ozzardi infection and corneal lesions with no evident etiology was observed in this study, but the lack of conclusive findings on histopathology and PCR make us doubt the corneal involvement in mansonelliasis. Large studies of high mansonelliasis prevalence populations and extensive employment of microfilaria identification tests in ocular tissue are needed to evaluate the microfilaria corneal pathogenicity.

Keywords: Mansonelíase/epidemiology; Eye infections, parasitic; keratitis/etiology; Microfilaria

\section{REFERÊNCIAS}

1. Tavares AM. Estudo da infecção por Mansonella ozzardi [tese]. Brasília: Universidade de Brasília; 1981.

2. Garrido C, Campos M. First report of presumed parasitic keratitis in Indians from the Brazilian Amazon. Cornea. 2000;19(6):817-9.

3. Morales-Hojas R, Post RJ, Shelley AJ, Maia-Herzog M, Coscarón S, Cheke RA. Characterisation of nuclear ribosomal DNA sequences from Onchocerca volvulus and Mansonella ozzardi (Nematoda: Filarioidea) and development of a PCR-based method for their detection in skin biopsies. Int J Parasitol. 2001;31(2):169-77. Erratum in: Int J Parasitol 2001;31(8):850-1.

4. Shelley AJ, Coscarón S. Simuliid blackflies (Diptera: Simuliidae) and ceratopogonid midges (Diptera: Ceratopogonidae) as vectors of Mansonella ozzardi (Nematoda: Onchocercidae) in northern Argentina. Mem Inst Oswaldo Cruz. 2001;96(4):451-8

5. Branco BC, Chamon W, Belfort R, Belfort Júnior R, Costa AJA. Achados oculares entre habitantes do Município de Pauiní e possível associação entre lesões corneanas e mansonelose na Amazônia. Arq Bras Oftalmol. 1998;61(6):647-82.

6. Martins AM, Pessoa FAC, Chagas AC, Andrade E, Borborema M, Dourado H. Situação atual da mansonelose na Cidade de Coarí, Estado do Amazonas, Brasil. In: XLIII Congresso da Sociedade Brasileira de Medicina Tropical; II Encontro de Medicina Tropical dos Países de Língua Portuguesa; I Encontro da Sociedade Brasileira de Medicina de Viagem, 2007, Campos do Jordão. Rev Soc Bras Med Trop. 2007;40(1):177.

7. Chaves CC. Oncocercose ocular na Amazônia brasileira [tese]. Ribeirão Preto: Faculdade de Medicina de Ribeirão Preto da Universidade de São Paulo; 1994.

8. Garrido CMB. Saúde ocular em comunidades de índios e não-índios da região do Alto Rio Negro, Estado do Amazonas, Brasil [tese]. São Paulo: Universidade Federal de São Paulo. Escola Paulista de Medicina; 2000. 